\title{
COMPARISON OF HEPATIC PROFILE IN PRE AND POSTOPERATIVE OF BARIATRIC SURGERY: PRIVATE VS PUBLIC NETWORK
}

\author{
Comparação do perfil hepático no pré e pós-operatório na cirurgia bariátrica: rede particular vs pública \\ Taianne Machado NASCIMENTO, Antônio ALVES-JÚNIOR, Marco Antonio Prado NUNES, \\ Tiago Rodrigo Pereira de FREITAS, Marco Antonio Fontes Sarmento da SILVA, Maria Rosa Melo ALVES
}

From the Hospital Universitário, Universidade Federal de Sergipe (University Hospital, Federal University of Sergipe), Aracaju, SE, Brazil.
HEADINGS - Non-alcoholic Fatty Liver Disease. Hepatic fibrosis. Obesity. Bariatric Surgery.
ABSTRACT - Background: Obesity is associated to several comorbidities, including nonalcoholic fatty liver disease, which implicates in isolated steatosis to steatohepatitis. The latter may progress to severe manifestations such as liver fibrosis, cirrhosis and hepatocellular carcinoma. Aim: To compare the presence of advanced liver fibrosis before and after bariatric surgery in patients of private and public health system. Methods: Patients from public and privative networks were studied before and after bariatric surgery. The presence or absence of advanced hepatic fibrosis was evaluated by NAFLD Fibrosis Score, a non-invasive method that uses age, $\mathrm{BMI}, \mathrm{AST} / \mathrm{ALT}$ ratio, albumin, platelet count and the presence or absence of hyperglycemia or diabetes. The characteristics of the two groups were compared. The established statistical significance criterion was $p<0.05$. Results: Were analyzed 40 patients with a mean age of $34.6 \pm 9.5$ years for private network and $40.6 \pm 10.2$ years for public. The study sample, $35 \%$ were treated at private health system and $65 \%$ in the public ones, $38 \%$ male and $62 \%$ female. Preoperatively in the private network one $(7.1 \%)$ patient had advanced liver fibrosis and developed to the absence of liver fibrosis after surgery. In the public eight (30.8\%) patients had advanced liver fibrosis preoperatively, and at one year after the proportion fell to six (23\%). Conclusion: The non-alcoholic fatty liver disease in its advanced form is more prevalent in obese patients treated in the public network than in the treated at the private network and bariatric surgery may be important therapeutic option in both populations.

\section{Correspondence:}

Taianne Machado Nascimento

E-mail: taianne.tai@gmail.com

Financial source: none

Conflicts of interest: none

Received for publication: 02/06/2015 Accepted for publication: 03/09/2015

DESCRITORES: Hepatopatia Gordurosa não Alcoólica. Fibrose hepática. Obesidade. Bariátrica.
RESUMO - Racional: A obesidade está relacionada com diversas comorbidades, entre elas a doença hepática gordurosa não-alcoólica, que inclui desde esteatose isolada à esteatohepatite. Esta última pode evoluir para manifestações mais graves, como fibrose hepática, cirrose e hepatocarcinoma. Objetivo: Comparar a presença de fibrose hepática avançada antes e após cirurgia bariátrica em pacientes da rede particular e pública. Métodos: Foram estudados pacientes antes e após operação bariátrica das redes particular e pública. A presença ou ausência de fibrose hepática avançada foi avaliada através do NAFLD Fibrosis Score, método não invasivo que utiliza idade, IMC, relação AST/ALT, albumina, contagem de plaquetas e presença ou ausência de hiperglicemia ou diabete. As características dos dois grupos foram comparadas $O$ critério de significância estatística estabelecido foi $p<0,05$. Resultados: Foram analisados 40 pacientes com idade média de $34,6 \pm 9,5$ anos para rede particular e 40,6 $\pm 10,2$ anos para pública. Da amostra avaliada, $35 \%$ foram atendidos no sistema de saúde particular e $65 \%$ no sistema público, sendo $38 \%$ gênero masculino e $62 \%$ feminino. No pré-operatório da rede particular um $(7,1 \%)$ paciente apresentou fibrose hepática avançada e evoluiu para ausência de fibrose hepática após o procedimento cirúrgico. Já na rede pública oito $(30,8 \%)$ apresentaram fibrose hepática avançada no pré-operatório, sendo que no pós de um ano esse valor foi para seis (23\%). Conclusão: A hepatopatia gordurosa não alcóolica na forma avançada é mais prevalente em pacientes obesos atendidos na rede pública do que nos da rede privada, sendo que a cirurgia bariátrica pode ser importante opção terapêutica em ambas populações.

\section{INTRODUCTION}

$\mathrm{T}$ he increase of body weight is a significant public health challenge ${ }^{11}$. It is estimated that more than 1.9 billion adults are overweight, and 600 million of these are obese ${ }^{24}$. In the United States, over $16.9 \%$ of young people and $34.9 \%$ of adults are considered obese ${ }^{16}$. In Brazil the prevalence of overweight in adults living in the capitals of the 26 states and the Federal District increased from $43.2 \%$ in 2006 to $51.0 \%$ by $2012^{13}$. If these recent trends continue, in 2030 to $57.8 \%$ of the adult population (3.3 billion people) will be overweight or obese ${ }^{11}$.

Obesity is a risk factor for several diseases, contributing to the global load of incapacitating and chronic disease ${ }^{15}$. Pathological conditions associated with obesity include some of the following disorders: cardiovascular, endocrine, respiratory, gastrointestinal, skin, genitourinary, musculoskeletal, neoplasms, psychosocial and some other implications, such as increased anesthetic and surgical risk and decreased physique alertness ${ }^{23}$. Obesity today is linked to more worldwide deaths than underweight ${ }^{24}$.

Clinical treatment is the first option. It usually includes the use of anorectic or disabsorptive medicines, besides psychological treatments, physical therapy, dietary and exercise ${ }^{5}$. However, clinical treatment does not deliver long-term significant results, 
while bariatric operation is the most effective tool to control and treat morbid obesity. Although invasive, it has achieved satisfactory results, leading to the reduction of more than $50 \%$ of the overweight or 30 to $40 \%$ of the initial weight. It aims the reduction of hunger signals and increased satiety, thus, producing a controlled state of undernutrition ${ }^{10,17,19}$.

Nonalcoholic fatty liver disease (NAFLD) is a condition defined by the excessive accumulation of fat that is not related to alcoholic consumption. This accumulation had its prevalence doubled during the past 20 years and it occurs in the form of triglycerides (steatosis), exceeding 5 to $10 \%$ of liver weight. A subset of patients presenting hepatic steatosis will evolve with steatohepatitis, dramatically increasing the risk of cirrhosis, liver failure and hepatocellular carcinoma. Currently, NAFLD and nonalcoholic steatohepatitis are considered the number one cause of hepatic illnesses in Western countries 8,12,21.

Abdominal ultrasound is the most frequently used complementary exam to diagnose hepatic steatosis both in clinical evaluations and in epidemiological studies. Despite the lower accuracy compared to tomography and magnetic resonance imaging and not being able to distinguish steatosis from liver steatohepatitis, this procedure has to be the easiest due to its noninvasive method. Additionally, it presents as less expensive when compared to other image methods $s^{4,7}$.

Liver biopsy is considered the gold standard for directly diagnosing NAFLD and evaluating the inflammation/fibrosis; however, its use is limited because it is invasive, has a high cost and presents sampling error or inadequate sample quantity. Thus, several noninvasive methods using panels of markers or counts, instead of biopsy, to identify patients with steatohepatitis or fibrosis, are being proposed. However, suitable decision algorithms validated for clinical practice are still scarce ${ }^{14}$.

A non-invasive test example is the NAFLD Fibrosis Score, developed and validated by Angulo et al. (2007). This scale measures the degree of advanced liver fibrosis from the calculated score based on six variables: age, BMI, relative AST/ALT, albumin, platelet count and presence or absence of hyperglycemia or diabetes to identify or exclude advanced liver fibrosis, defined as stages 3 and 4 of the proposed classification by Brunt, which evaluates the fibrotic stage of the histology based on five points ${ }^{1,18}$.

The aim of this study was to compare the presence of nonalcoholic fatty liver disease in obese patients before and after bariatric surgery between the private and public network.

METHOD

Patients participated in this study by their own free will, and have undergone the signature of a term of consent. The research project was approved by the Ethics Committee of Human Research at the Federal University of Sergipe, under Protocol No 17402613.1.0000.5546.

The initial sample was 65 patients from the public network and 107 patients from the private network after bariatric surgery by the same surgeon and accompanied by the same multidisciplinary team, therefore, subjected to even pre, intra and postoperatively accompanying protocol. It was excluded those who did not agree to participate, did not have sufficient postoperative time, did not follow up on services or whose necessary data to complete the study were not available, patients with no evidence of hepatic steatosis by imaging and other suspected causes of liver disease, as assessed by clinical examination and serology for hepatitis $B$, hepatitis $C$ and HIV. Alcohol consumption was evaluated through interviews with patients, here defined as exclusion factor a weekly consumption higher than $210 \mathrm{~g}$ for men and $140 \mathrm{~g}$ for women ${ }^{1}$. After applying the exclusion criteria, the final study sample was composed of 40 patients, among them 14 from the public network and 26 from the private. Patients of the public network have been seen, operated and monitored in the University Hospital of the Federal University of Sergipe. The private network patients have been seen in private offices and operated in private hospitals. In both cases, they had the same surgical team, same nutritional and psychological protocols.

The patients underwent vertical banded gastroplasty with gastrojejunal derivation in Roux-en-Y. Anthropometric characteristics were evaluated (gender, age, weight, BMI) and laboratory (blood glucose, platelet counts and determination of serum aspartate aminotransferase - AST, alanine aminotransferase - ALT and albumin) and the presence or absence of hyperglycemia in the preoperative and postoperative period of six months and one year.

The presence or absence of advanced hepatic fibrosis was assessed by the Non-Alcoholic Fatty Liver Disease Fibrosis Score (NAFLD Fibrosis Score). For the calculation of the index it was used: age in years, BMI in $\mathrm{kg} / \mathrm{m}^{2}$, determination of serum AST and ALT U/l, serum albumin in $\mathrm{g} / \mathrm{dl}$, and the presence of diabetes mellitus and hyperglycemia (blood glucose equal or higher than $110 \mathrm{mg} / \mathrm{dl}$ ). The calculation was performed according to the following formula: NAFLD Fibrosis Score $=$ $-1.675+0.037 \times$ age (years) $+0.094 \times \mathrm{BMI}\left(\mathrm{kg} / \mathrm{m}^{2}\right)+1.13$ $\times$ hyperglycemia/diabetes mellitus (yes $=1$, no $=0)+0.99 \times$ AST / ALT ratio $-0.013 \times$ platelets $\left(\times 10^{9} / \mathrm{l}-0.66 \times\right.$ Albumin, $\mathrm{g} / \mathrm{dl}$ ). Values below -1.455 indicate absence of fibrosis advanced liver and above 0.676 the presence of advanced hepatic fibrosis. Values from -1.455 to 0.676 are considered indeterminate regarding the presence of advanced fibrosis.

Data analysis was performed using descriptive statistics in which the categorical variables were expressed as absolute and relative frequencies and numeric variables were presented as central tendency measurements and variability. The characteristics of the two groups were compared by the chi-square test in the case of categorical variables and the Student's t-test for independent samples in the case of numerical variables. For repeated measures, analysis of variance (ANOVA) was used for comparisons between groups and moments (preoperatively, six months and one year). The established statistical significance criterion was $p<0.05$.

\section{RESULTS}

Forty patients were analyzed, of which $35 \%(14 / 40)$ were seen at supplemental health system and $65 \%(26 / 40)$ in the public health system. The entire sample had a mean age of 39 years (C195\%: $35-42$ years); the vast majority, $62 \%$, of females $(27 / 40)$ and only $38 \%$ male (13/40). From the private network, 11 were women $(79 \%)$ and three men $(21 \%)$ and from the public network 16 women (62\%) and 10 men (38\%). (Table 1)

TABLE 1 - Clinical data characterization of preoperative patients treated at private and public network

\begin{tabular}{|c|c|c|c|c|c|c|}
\hline & \multicolumn{2}{|c|}{ Private } & \multicolumn{2}{|c|}{ Public } & \multirow{2}{*}{ Total } & \multirow{2}{*}{$\mathrm{p}$} \\
\hline & $\mathrm{n}$ & $\%$ & $\mathrm{n}$ & $\%$ & & \\
\hline \multicolumn{7}{|l|}{ Gender } \\
\hline Male & 3 & $21 \%$ & 10 & $38 \%$ & 13 & 0,316 \\
\hline Female & 11 & $79 \%$ & 16 & $62 \%$ & 27 & \\
\hline \multicolumn{7}{|c|}{ Hyperglycemia - diabetes mellitus } \\
\hline No & 11 & $79 \%$ & 17 & $65 \%$ & 28 & 0,484 \\
\hline Yes & 3 & $21 \%$ & 9 & $35 \%$ & 12 & \\
\hline \multicolumn{7}{|l|}{ Fibrosis degree } \\
\hline No fibrosis & 10 & $71 \%$ & 6 & $23 \%$ & 16 & 0,011 \\
\hline Indeterminate & 3 & $21 \%$ & 12 & $46 \%$ & 15 & \\
\hline With fibrosis & 1 & $7 \%$ & 8 & $31 \%$ & 9 & \\
\hline Total & 14 & $100 \%$ & 26 & $100 \%$ & 40 & \\
\hline
\end{tabular}


The average $\mathrm{BMI}$ in the preoperative private and public networks were respectively $39.1 \pm 4.7 \mathrm{~kg} / \mathrm{m}^{2}$ and $47.8 \pm 2.3$ $\mathrm{kg} / \mathrm{m}^{2}$; after postoperative six months follow-up these values were $29.5 \pm 4.9 \mathrm{~kg} / \mathrm{m}^{2}$ and $35.6 \pm 8.7 \mathrm{~kg} / \mathrm{m}^{2}$; and in the postoperative period of one year values were $26.9 \pm 4.0$ $\mathrm{kg} / \mathrm{m}^{2}$ and $32.8 \pm 9 \mathrm{~kg} / \mathrm{m}^{2}$, observing statistically significant reduction $(p<0.001)$.

In relation to the private network, there was a significant statistical difference when collated preoperative and postoperative individual values of $B M I$ and weight $(p<0.05)$; however, AST, ALT, albumin and NAFLD did not represent statistical differences ( $p>0.05)$. Table 2 shows the characterization of the private network patients concerning anthropometric and laboratory variables evaluated.

TABLE 2 - Characteristics of the private network sample during periods of observation: preoperative, six months and 12 months of postoperative.

\begin{tabular}{c|c|c|c|c|c|} 
& $\begin{array}{c}\text { Preoperative } \\
\text { Average (SD) }\end{array}$ & $\begin{array}{c}\text { Six-month } \\
\text { Average (SD) }\end{array}$ & $\begin{array}{c}\text { One-year } \\
\text { Average (SD) }\end{array}$ & $\begin{array}{c}\text { Total } \\
\text { Average (SD) }\end{array}$ & $p$ \\
\hline BMI & $39,1(4,7)$ & $29,5(4,9)$ & $26,9(4,0)$ & $31,8(7,0)$ & $<0,001$ \\
\hline AST & $27,2(12,0)$ & $25,1(9,0)$ & $32,1(31,4)$ & $28,2(19,8)$ & 0,649 \\
\hline ALT & $37,5(33,3)$ & $27,8(17,1)$ & $31,4(16,8)$ & $32,2(23,4)$ & 0,477 \\
\hline Albumin & $4,1(0,26)$ & $4,0(0,33)$ & $4,2(0,39)$ & $4,1(0,33)$ & 0,341 \\
\hline Weight & $108,1(24,4)$ & $81,6(21,7)$ & $73,7(13,0)$ & $87,8(24,8)$ & $<0,001$ \\
\hline NAFLD & $-2,1212(1,65)$ & $-2,5088(1,19)$ & $-3,0400(0,93)$ & $-2,5567(1,32)$ & 0,086 \\
\hline
\end{tabular}

$\mathrm{BMI}=$ Body Mass Index; NAFLD score $=$ nonalcoholic fatty liver disease

As for the public, there was significant statistical difference when compared preoperative and postoperative individual values of BMI, weight and NAFLD. AST, ALT and albumin values did not show statistical differences. Table 3 shows the characterization of public network patients concerning anthropometric and laboratory variables evaluated.

TABLE 3 - Characteristics of the public network sample during the following periods of observation: preoperative, six months and 12 months of postoperative.

\begin{tabular}{|c|c|c|c|c|c|} 
& $\begin{array}{c}\text { Preoperative } \\
\text { Average (SD) }\end{array}$ & $\begin{array}{c}\text { Six-month } \\
\text { Average (SD) }\end{array}$ & $\begin{array}{c}\text { One-year } \\
\text { Average (SD) }\end{array}$ & $\begin{array}{c}\text { Total } \\
\text { Average(SD) }\end{array}$ & $p$ \\
\hline BMI & $47,8(12,3)$ & $35,6(8,7)$ & $32,8(9,0)$ & $38,8(12,0)$ & $<0,001$ \\
\hline AST & $25,2(9,5)$ & $30,0(16,2)$ & $29,8(19,7)$ & $28,3(15,7)$ & 0,296 \\
\hline ALT & $35,9(25,6)$ & $36,7(19,2)$ & $33,8(17,6)$ & $35,5(21,0)$ & 0,788 \\
\hline Albumin & $3,8(0,48)$ & $3,8(0,52)$ & $3,9(0,54)$ & $3,9(0,51)$ & 0,663 \\
\hline Weight & $128,5(34,3)$ & $95,9(24,7)$ & $87,9(22,6)$ & $104,1(32,6)$ & $<0,001$ \\
\hline NAFLD & $-0,6845(2,17)$ & $-1,3298(1,68)$ & $-1,6898(1,91)$ & $-1,2347(1,96)$ & 0,0002 \\
\hline
\end{tabular}

$\mathrm{BMI}=$ Body Mass Index; NAFLD score=nonalcoholic fatty liver disease.

By applying the NAFLD Fibrosis Score, before the operation, the presence of preoperative advanced liver fibrosis was identified in one $(7.1 \%)$ patient in the private network and eight $(30.8 \%)$ in public; the intermediate degree of fibrosis and absence of fibrosis were for private and public networks of, respectively, three (21.4\%) and 12 (46.2\%); and $10(71.4 \%)$ and six $(23.1 \%)$ in this period, presenting statistical significance $(p<0.05)$ (Table 1).

After the surgery, the presence of advanced liver fibrosis was not identified in any patient of the private network, in both of the six-month and one-year postoperative. This group obtained intermediate values and without fibrosis in the postoperative period of six months, respectively, two (14.3\%) and 12 (85.7\%), and after 12 months, one (7.1\%) and $13(92.9 \%$ - Figure 1)

In public network, six (23.1\%) patients had advanced fibrosis during the period after six months and one year. In this network, there were intermediate values of fibrosis: nine $(34.7 \%)$ in the postoperative period of six months and 10 (38.5\%) in a year. It was classified as no fibrosis 11 (42.3\%) patients after six months and $10(38.5 \%)$ in a year of the public network (Figure 2).

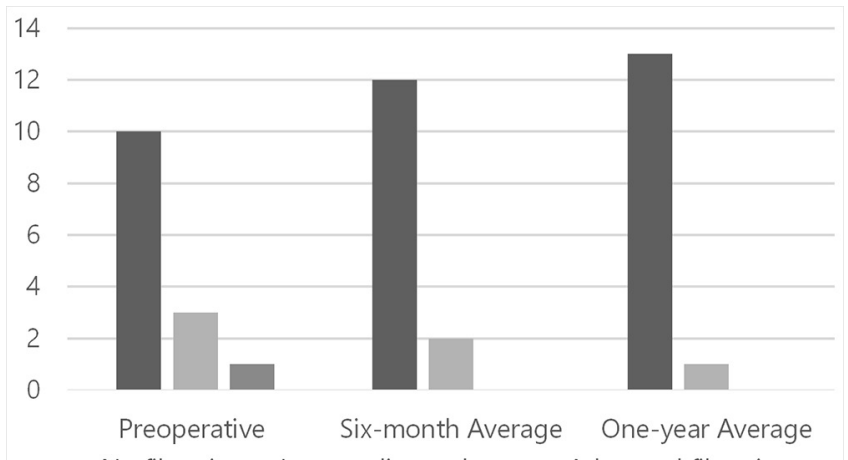

no fibrosis Intermediate values Advanced fibrosis

FIGURE 1 - Graphic representation of the number of patients served by supplementary care network, with the degree of fibrosis liver defined by NAFLD (nonalcoholic fatty liver disease)

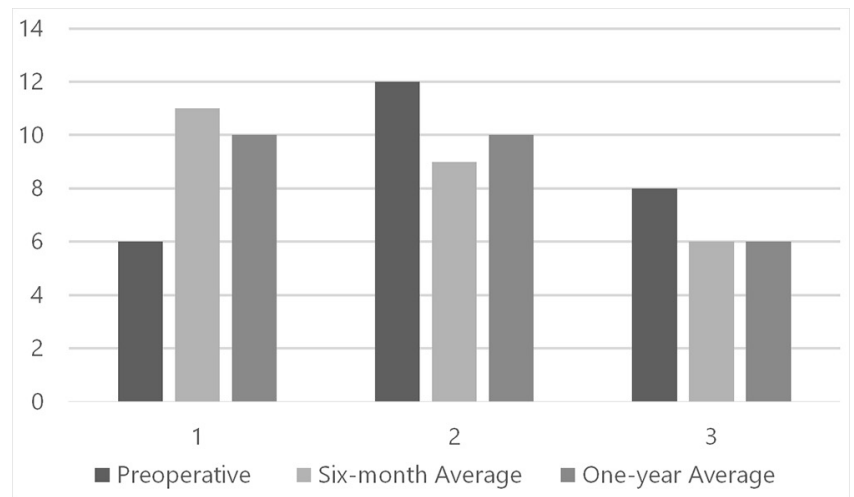

FIGURE 2 - Graphic representation of the number of patients served by public health, with the degree of liver fibrosis defined by NAFLD (nonalcoholic fatty liver disease)

From the sample evaluated, among the nine patients with advanced fibrosis before operation, one (11.1\%) stopped presenting advanced fibrosis and three (33.3\%) went to the indeterminate range. Regarding the 15 patients with indeterminate score, seven (46.7\%) stopped presenting postoperative advanced fibrosis, whereas seven $(46.7 \%)$ remained with indeterminate score and one $(6.7 \%)$ evolved with indeterminate fibrosis. The three patients without preoperative advanced fibrosis remained so after the surgery.

Except for two (5\%) patients, all have reduced the value of score after the procedure.

\section{DISCUSSION}

The prevalence of obesity is increasing ${ }^{24}$, which contributes to the load of global chronic diseases ${ }^{15}$. One of these diseases is NAFLD, having obesity as one of the main risk factors ${ }^{3}$. The justification for this phenomenon is that the increase of the release of free fatty acids, resistin, IL-6 and TNF-alpha by the adipose tissue and the reduction of the release of adiponectin contribute to the development of insulin resistance in obesity and increased risk of developing NAFLD ${ }^{6}$.

Other studies determine the prevalence of non-alcoholic liver disease in patients referred for bariatric surgery. Marceau et al. demonstrated prevalence of $86 \%$ to steatosis, $23 \%$ to steatohepatitis and $2 \%$ to cirrhosis among 551 patients 9 .

In the present study, the mean BMI before operation was higher for public patients $47.8 \pm 2.3 \mathrm{~kg} / \mathrm{m}^{2}$, which rates it, in level of obesity, greater than the private network $39.1 \pm 4.7$ $\mathrm{kg} / \mathrm{m}^{2}$. These data corroborate the literature, since there is an 
inverse relationship between the socioeconomic level and the prevalence of obesity. Furthermore, there is also an association between income and consumption of leafy vegetables; thus, individuals with lower incomes are less likely to consume these foods, which are important for low-calorie diet and healthy eating habits ${ }^{20}$.

In the overall sample, $27(67.5 \%)$ were women and $13(32.5 \%)$ men. Among the private network, there were 11 women $(79 \%)$ and three $(21 \%)$ men and the public network was composed of 16 (62\%) women and 10 (38\%) men. Another aspect observed in the studies is the predominance of women in the cases of bariatric surgery in Brazil. This may be related to the higher prevalence of obesity among females, to the different determinants of obesity between the sexes and/or to the fact that obese women may show greater motivation for the pursuit of weight loss, mainly due to social pressures ${ }^{2}$.

There were differences in terms of age $(p=0.078)$ showing values of $34.6 \pm 9.5$ years for private and $40.6 \pm 10.2$ years for public networks. This can be a consequence of the average waiting time difference of the patients for concluding the transaction by SUS and by the Supplementary Health Network. In SUS, patients wait for 2.9 years, while patients who have private health insurance can carry it out with the minimum time interval since the first appointment, only having to meet the clinical requirements for realizing $i^{22}$.

The prevalence of steatohepatitis not alcoholic in the US population is of $30 \%$, while in patients undergoing bariatric surgery is $90 \%$. The identification of the presence and severity of hepatic fibrosis in patients with steatosis liver is crucial for the subsequent orientation management, since the ones with fibrosis have higher risk for cirrhosis, portal hypertension, hepatocellular carcinoma and death ${ }^{18}$

Among the 40 patients, nine had preoperative advanced liver fibrosis; of these, eight (88.9\%) were from the public network, responsible for a higher mean BMI than the private one. This is in agreement with the literature, because according to the National Health and Nutrition Examination Survey III, the prevalence of primary non-alcoholic liver disease increases according to the $\mathrm{BMI}^{9}$.

Of the 14 patients in the private network, 13 (92.8\%) had a $<-1.455$ score in the postoperative of one year and, thus, the absence of advanced liver fibrosis. Only one patient in the preoperative was classified as a carrier of the disease, which evolved after the weight loss to the fibrosis resolution. In the public network, there were 26 patients and after a year procedure, the number of advanced fibrosis patients was six $(23 \%)$. The number of those who did not have fibrosis preoperatively rose from six to $10(38.4 \%)$ after one year, demonstrating the therapeutic effect of bariatric surgery and weight loss caused by it.

The private network evolved with a higher percentage of patients without advanced liver fibrosis after a year of surgery; this probably is closely related to the lower BMl of these patients when compared to the public network ones.

Both obesity and nonalcoholic fatty liver disease are rising diseases and deserve further studies and papers involving their relations. Including the continuation of this research to remedy some limitations, such as the expansion of the casuistry and the follow-up time to ratify the results found herein.

\section{CONCLUSION}

Non-alcoholic fatty liver disease in an advanced form is more prevalent in obese patients seen in the public network than those in private ones, and bariatric surgery may be an important therapeutic option in both populations.
REFERENCES

1. Angulo $P$, Hui JM, Marchesini $G$, at al. The NAFLD Fibrosis Score: $A$ Noninvasive System That Identifies Liver Fibrosis in Patients with NAFLD. Hepatology 2007; 45(4):846-854.

2. Barros LM, Frota NM, Moreira RAN, Araújo TM, Caetano JA. Avaliação dos resultados da cirurgia bariátrica. Rev. Gaúcha Enferm. 2015 Mar;36( 1 ):21-27.

3. Bitencourt AGV, Cotrim HP, Alves E, Almeida AM, Barbosa DBV, Santos ASetal.Doençahepáticagordurosanãoalcoólica:característicasclínicas e histológicas em obesos graves submetidos à cirurgia bariátrica. Acta Gastroenterol Latinoam. 2007;37:224-30.

4. Boente L, Soares D, Leal R, Campos F, Araújo C, D'AlmeidaFetal.Doença hepática gordurosa não-alcoólica: importância da ultra-sonografia abdominal no diagnóstico. Gazeta Médica da Bahia 2011 Jan;81(1):7-9.

5. Costa ACC, Ivo ML, Cantero WB, Tognini JRF. Obesidade em pacientes candidatos a cirurgia bariátrica 2009 Jan;22(1):55-59.

6. De Souza AV, Guedes JC, Mazini Filho ML, Condessa VA, Condessa LA, De Jesus RP. Doença hepática gordurosa não alcoólica: Revisão de literatura. Rev. Ciências em Saúde 2014 Jan;4(1):47-56.

7. EiflerRV.Opapel daultrassonografia namedida dagordura subcutânea e visceral e sua correlação com a esteatose hepática. Radiol Bras 2013 Set; 46(5):273-8.

8. Feijo SG, Lima JMC, De Oliveira MAA, Patrocínio RMV, Moura-Júnior LG, Campos AB et al. The spectrum of non alcoholic fatty liver disease in morbidly obese patients: prevalence and associate risk factors. Acta Cir. Bras. 2013 Nov;28(11):788-793.

9. Freitas ACT, Freitas DT, Parolin MB, Campos ACL, Coelho JCU. Doença hepática não-alcoólica: evolução após derivação gastrojejunal em Y-de-Roux pela técnica de fobi-capella. Arq. Gastroenterol. 2007 Mar;44,(1):49-53.

10. Jóia-Neto L, Lopes-Junior AG, Jacob CE. Alterações metabólicas e digestivas no pós-operatório de cirurgia bariátrica. $A B C D$, arq. bras. cir. dig. 2010 Dez;23(4):266-269.

11. Kelly T, Yang W, Chen C-S, Reynolds K, He J. Global burden of obesity in 2005 and projections to 2030. International Journal of Obesity 2008 Jul;32:1431-1437.

12. LaBrecque $D R$, Abbas $Z$, Anania F, Ferenci $P$, Khan AG, Goh KL et al. World Gastroenterology Organisation global guidelines: Nonalcoholic fatty liver disease and nonalcoholic steatohepatitis. Journal of clinical gastroenterology 2014 Jul;48(6):467-473.

13. Malta DC, Andrade SC, Claro RM, Bernal RTI, Monteiro CA. Trends in prevalence of overweight and obesity in adults in 26 Brazilian state capitals and the Federal District from 2006 to 2012. Rev. Bras. de Epidemiol. 2014;17( Suppl 1): 267-276.

14. Nascimbeni F, Pais R, Bellentani S, Day CP, Ratziu V, Loria P et al. From NAFLD in clinical practice to answers from guidelines. Journal of hepatology 2013;59(4):859-871.

15. Nissen LP, Vieira LH, Bozza LF, Da Veiga LT, Biscaia BFL, Pereira JH et al. Intervenções para tratamento da obesidade: revisão sistemática. Rev. Brasil. de Med. de Família e Comunidade 2012;7,(24):184-190.

16. Ogden CL, Carroll MD, Kit BK, Flegal KM. Prevalence of Childhood and AdultObesityintheUnitedStates, 2011-2012.JAMA.2014;311(8):806-814

17. Pedrosa IV, Burgos MGPA, Souza NC, Morais CN. Aspectos nutricionais em obesos antes e após a cirurgia bariátrica. Rev. Col. Bras. Cir. 2009 Ago;36(4):316-322.

18. Pimentel SK, Strobel R, Gonçalves CG, Sakamoto DG, Ivano FH, Coelho JCU. Evaluation of the nonalcoholic fat liver disease fibrosis score for patients undergoing bariatric surgery. Arq. Gastroenterol. 2010 Jun:47(2):170-173

19. RavelliMN, etal. Obesidade, cirurgia bariátricaeimplicações nutricionais. Rev. Bras. em Promoção da Saúde 2012;20(4):259-266

20. Rodrigues APS; Da Silveira EA. Correlação e associação de renda e escolaridadecomcondições desaúdeenutriçãoemobesosgraves. Ciênc. saúde coletiva 2015 Jan;20(1):165-174.

21. Salgado JuniorW, Dos SantosJS, SankarankuttyAK, SilvaOC. Nonalcoholic fatty liver disease and obesity. Acta Cir. Bras. 2006;21(supl. 1):72-78.

22. Santos HN, Lima JMS, De Souza MFC. Estudo comparativo da evolução nutricional de pacientes candidatos à cirurgia bariátrica assistidos pelo Sistema Único de Saúde e pela Rede Suplementar de Saúde. Revista Ciência \& Saúde Coletiva 2014 Maio;19(5):1359-365

23. Tavares TB, Nunes SM, Santos MO. Obesidade e qualidade de vida: revisão da literatura. Rev. Méd. de Minas Gerais 2010 Jul;20(3):359-366.

24. World Health Organization [homepage na internet]. Obesity and overweight. Fact sheet $N^{\circ} 311$, Updated January 2015. [acesso em 22 de junho de 2015]. Disponível em: http://www.who.int/mediacentre/ factsheets/fs311/en/ 